\author{
Marta Boguś \\ Uniwersytet Pedagogiczny \\ im. Komisji Edukacji Narodowej \\ w Krakowie
}

\title{
Proces ksztaltowania się korporacji ponadnarodowej Google
}

Charakterystyczny i nieodłączny element współczesnej gospodarki światowej stanowią korporacje ponadnarodowe, będące motorem napędowym i głównymi beneficjentami nasilających się procesów globalizacji (Zorska 1998). „Korporacje ponadnarodowe prowadzą własną politykę rozwoju, zmierzając do podnoszenia swojej konkurencyjności w drodze rozwoju badań naukowych i wprowadzania nowych produktów, opanowywania rynku, przepływu informacji, produktów, technologii itp.” (Zioło 2001, s. 29-30). Posiadają one duży potencjał ekonomiczny oraz zdolności integrowania i koordynowania wielkich systemów produkcyjnych, usługowych i finansowych (Zorska 1998), dlatego odgrywają ważną rolę w wytyczaniu reguł funkcjonowania gospodarki światowej. Korporacje poszukują miejsc efektywnej lokalizacji i oplatają świat, warunkując funkcjonowanie innych firm na terenie poszczególnych krajów oraz regionów (Zioło 2009), co powoduje, że są określane jako ,specyficzne podmioty «władzy» w stosunkach międzynarodowych" (Piórko 2008, s. 49).

W XXI w. - erze wiedzy lub erze interakcyjno-intelektualnej - jednym z filarów są technologie informatyczne, które odgrywają ważną rolę w poszczególnych etapach przetwarzania danych oraz tworzeniu innowacyjnych produktów i usług (Olszak 2007). Przemysł wysokiej technologii (high-technology industries), oparty głównie na przemyśle informatycznym, stanowi potężną siłę wytwórczą i traktowany jest jako przełom w rozwoju ludzkości porównywalny z wynalezieniem maszyny parowej (Wieloński 2003).

„Proces kształtowania się korporacji światowych stymulowany jest poprzez mechanizmy konkurencji dokonujące się na rynku globalnym” (Zioło 2009, s. 12). W świetle przedstawionych przesłanek w niniejszych rozważaniach podjęto analizę procesu kształtowania się korporacji ponadnarodowej Google. „Odkąd przed ponad pięcioma stuleciami Goutenberg skonstruował nowoczesną prasę drukarską, dzięki czemu wszelkiego rodzaju publikacje stały się tańsze i powszechniej osiągalne, żaden inny wynalazek nie zrewolucjonizował dostępu do informacji w takim stopniu, jak wyszukiwarka Google" (Vise 2007, s. 3).

\section{Zarys rozwoju firmy}

Historia powstania firmy Google sięga 1995 r., kiedy dwaj matematycy - Amerykanin Larry Page i Rosjanin Sergey Brin - poznali się na Uniwersytecie Stanfordzkim. Larry Page, doktorant Wydziału Informatyki, podjął pracę na temat wyszukiwania informacji w sieci WWW. Fascynacja Internetem i mechanizmami nim rządzącymi, która połączyła matematyków, i owocne badania doprowadziły do powstania systemu BackRub ${ }^{1}$, wzbogaconego później

\footnotetext{
${ }^{1} \mathrm{~W}$ języku polskim 'masaż pleców', od amerykańskiego powiedzonka ,ty pomasujesz moje plecy, ja pomasuję twoje". Nawiązuje do mechanizmu indeksacji, który hierarchię stron tworzy na podstawie liczby odnośników prowadzących do danego adresu.
} 
o przełomowy algorytm PageRank wykorzystany w prototypie wyszukiwarki internetowej. Pierwsza wersja wyszukiwarki ukazała się w serwisie Stanforda w 1996 r. Rozrastający się studencki projekt został przeniesiony z pokoju w akademiku prywatnego Uniwersytetu Stanfordzkiego mieszczącego się w Dolinie Krzemowej (stan Kalifornia, Stany Zjednoczone) do nowego biura w słynnym dziś garażu, w kalifornijskiej miejscowości Menlo Park.

W 1997 r. wyszukiwarce nadano nazwę Google, pochodzącą od terminu matematycznego googol, oznaczającego cyfrę 1 i 100 zer, odzwierciedlającego nieskończoną ilość informacji w Internecie.

W 1998 wynalazcy założyli spółkę akcyjną o kapitale początkowym 1,1 mln USD, zgromadzonym dzięki inwestorom, przy czym 100 tys. USD zainwestował Andy Bechtolsheim - jeden z założycieli Sun Microsystems. Dnia 7 września 1998 r. firma Google Inc. na czele z prezesem Page'em i dyrektorem Brinem rozpoczęła oficjalną działalność. Strona główna wyszukiwarki dzięki nieskomplikowanej formie okazała się jej atutem, a proste logo umieszczone na białym tle pozytywnie wyróżniało się w pełnym przepychu Internecie (ryc. 1). Jednak firma Google musiała stawić czoła silnej konkurencji. Na rynku wyszukiwarek istniały już wtedy m.in. Yahoo (ok. 40\% udziałów w rynku wyszukiwarek) oraz MSN (ponad 20\% udziałów).

Ryc. 1. Historyczne, pierwsze logo Google z 1998 r.

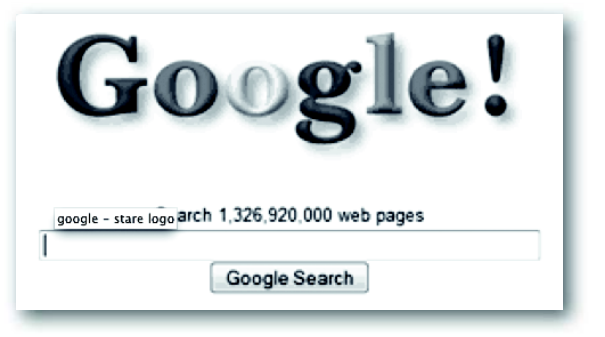

Źródło: http://openzone.pl/news,krotka-historia-google,3000

W 1999 r. firma Google przeniosła się z garażu do obecnej siedziby w Mountain View, w Dolinie Krzemowej, nazywanej Googleplex i uznawanej dziś za jedną ze światowych stolic branży informatycznej. Wizerunek korporacji wzbogacił się o logo i szatę graficzną. Wyszukiwarka obsługiwała wtedy 3 mln zapytań dziennie i została umieszczona przez magazyn „Time” w podsumowaniu kategorii „najlepsza technologia cyfrowa 1999”. Pod koniec roku firma zatrudniała 39 osób, w większości inżynierów różnych specjalizacji.

Firma Google przetrwała załamanie rynku dot-comów ${ }^{2}$ i rozwijała się od tego czasu dzięki prywatnym inwestorom. Zawarcie umowy z Yahoo potwierdzało skuteczność technologii. Nowym źródłem dochodów spółki stała się usługa AdWords. Pod koniec roku wyszukiwarka obsługiwała 60 mln zapytań dziennie, a liczba zatrudnionych w firmie wzrosła do ok. 150 osób.

W 2001 r. na stanowisku dyrektora generalnego zasiadł Eric Schmidt. Korporacja międzynarodowa uruchomiła swoją pierwszą filię w Tokio, zatrudniała ponad 200 pracowników, a jej usługi były dostępne w 26 językach. Wyszukiwarka obsługiwała ponad $100 \mathrm{mln}$ zapytań dziennie.

W 2002 r. firma udostępniła wyszukiwarkę obrazów, która już na początku indeksowała 250 mln plików graficznych, a także usługę Google News, dającą dostęp do wiadomości

\footnotetext{
${ }^{2}$ Okres euforii na giełdach całego świata w latach 1995-2001 związany ze spółkami z branży informatycznej i z pokrewnych sektorów, a dotyczący przeceniania przedsiębiorstw, które prowadziły lub zamierzały rozpocząć prowadzenie działalności w Internecie.
} 
z 4000 różnych źródeł. Wprowadziła także urządzenie indeksujące Google Appliance służące do zarządzania wyszukiwaniem i strukturą sieci lokalnych, weszła na rynek urządzeń mobilnych oraz uruchomiła nową wersję AdWords. Firma oferowała usługi w ponad 40 językach. Jej ogólny dochód w 2002 r. wynosił $440 \mathrm{mln}$ USD, a zysk netto prawie $100 \mathrm{mln}$ USD. Stowarzyszenie American Dialect Society uznało wyraz google najistotniejszym i najczęściej używanym słowem roku 2002 (Word of the Year) (Battelle 2006).

W latach 2003-2004 firma Google odniosła pasmo sukcesów poprzez m.in. uruchomienie platformy blogowej Blogger, usługi AdSense, która umożliwiała zarabianie na reklamach kontekstowych na własnej stronie, programu Picasa. Larry Page i Sergey Brin zostali określeni przez Stowarzyszenie Marconi Society za twórców trwałego wkładu w naukowy postęp ludzkości w dziedzinie komunikacji oraz Internetu.

W 2004 r. swoją premierę miał Gmail. W tym samym roku, 19 sierpnia, firma Google Inc. weszła na amerykańską giełdę przy Wall Street. Cena za akcję, wynosząca 85 USD, pozwoliła na zgromadzenie ok. 2 mld USD. Żadna inna firma z branży nie osiągnęła takiego pułapu. Od tej chwili nastąpiło przyspieszenie ekspansji korporacji.

W 2005 r. firma Google poczyniła milowy krok w dziedzinie wyszukiwania obrazów (Image Search), udostępniając ich w sieci ponad miliard. Ruszyła usługa Google Maps oraz Google Earth. Pobity także został rekord związany z wartością jednej akcji: cena za jedną wynosiła ponad 300 USD, a za wszystkie - ponad 80 mld USD.

Rok 2006 przyniósł ze sobą głównie doskonalenie oferty firmy. Dynamicznie rozwijająca się korporacja zakupiła serwis YouTube, Google Apps i Google Docs. Zapowiedziała także pojawienie się systemu operacyjnego dla urządzeń mobilnych - Android. Wyszukiwarka indeksowała $1000000 \mathrm{mln}$ stron internetowych dziennie.

W 2008 r. firma Google obchodziła dziesięciolecie istnienia. Udostępniono wtedy przeglądarkę Chrom, która w ciągu 10 godzin od premiery przekroczyła 1\% udziału w światowym rynku wyszukiwarek, czyli w ciągu tego czasu pobrano ją $14 \mathrm{mln}$ razy. W 2008 r. do sprzedaży trafił też pierwszy telefon komórkowy oparty na systemie Android - G1 w sieci T-Mobile.

W 2009 r. korporacja wprowadziła usługę Google Latitude oraz nowe narzędzie - Google Wave, a także zapowiedziała pojawienie się systemu operacyjnego ChromeOS przeznaczonego głównie dla urządzeń mobilnych. W połowie 2010 r. działalność rozpoczął serwis Google Books, utworzony w celu sprzedaży książek internetowych.

\section{Współczesna struktura przestrzenna działalności Google}

Korporacje ponadnarodowe szukają nowych miejsc efektywnej lokalizacji. Rozmieszczenie firm informatycznych na świecie jest związane z poziomem rozwoju gospodarczego, zasobami pracy i uwarunkowaniami ekonomicznymi (Kilar 2009). Coraz częściej za granicą kraju macierzystego lokalizuje się ośrodki badań naukowych i prac rozwojowych, w celu przejęcia lub wykorzystania zaawansowanych zdolności technologicznych tamtejszych ośrodków naukowo-badawczych oraz wysoko wykwalifikowanej kadry.

Założyciele Google pracę nad swoim projektem, który rozpowszechnił się wśród poszukujących informacji internautów na całym świecie, rozpoczęli w pokoju akademika Uniwersytetu Stanfordzkiego. Od tamtej pory nastąpił dynamiczny rozwój firmy. Charakterystyczną cechą korporacji ponadnarodowych jest rozprzestrzenianie ich działalności obejmujące coraz to nowe obszary. Poszczególne oddziały korporacji Google zlokalizowane są w 39 państwach na terenie 70 miast świata. Biura firmy umiejscawiane są zazwyczaj w stolicach tych krajów lub innych dużych miastach, co ma związek z głównymi rynkami odbiorców.

Dla korporacji oferującej usługi związane $\mathrm{z}$ wyszukiwaniem lokalizacja biur rozwojowych na całym świecie stanowi jeden z elementów strategii sukcesu, ponieważ dzięki temu jest 
W stanie skuteczniej adaptować usługi i produkty do lokalnych potrzeb. Jakość i cechy intelektualne klientów są ważnym źródłem wiedzy w rozwoju i stymulowaniu do działań innowacyjnych (Olszak 2007). Google chce w dalszym ciągu podążać według obranej strategii, a przestrzenne rozmieszczenie biur firmy nawiązuje do poziomu rozwoju ekonomicznego oraz zasobów intelektualnych, które są podstawowym warunkiem rozwoju branży informatycznej.

Jak już zostało powiedziane, główna siedziba korporacji znajduje się w Mountain View, w Stanach Zjednoczonych. Najwięcej oddziałów zlokalizowanych jest na terenie Ameryki Północnej i Europy (po 23 oddziały). Duże skupienie oddziałów występuje także w Azji (16). Dwa oddziały znajdują się w Ameryce Południowej, a najmniej, bo tylko jeden oddział, znajduje się w Australii (tab. 1) .

Tab. 1. Lokalizacja oddziałów firmy Google wg kontynentów

\begin{tabular}{|c|c|c|}
\hline Kontynent & Liczba oddziałów & Udział w ogóle oddziałów \\
\hline Europa & 23 & 35,4 \\
\hline Ameryka Północna & 23 & 35,4 \\
\hline Azja & 16 & 24,6 \\
\hline Ameryka Południowa & 2 & 3,1 \\
\hline Australia & 1 & 1,5 \\
\hline Ogółem & 65 & 100,0 \\
\hline
\end{tabular}

Źródło: opracowanie własne na podstawie www.google.com.

Poszczególne kraje charakteryzują się zróżnicowanym występowaniem biur korporacji Google. Najwięcej oddziałów korporacji znajduje się w Stanach Zjednoczonych, gdzie zlokalizowane są w 18 miastach (łącznie z siedzibą główną). Stosunkowo duża liczba oddziałów występuje także na obszarze Indii, gdzie Google ma swoją siedzibę w czterech miastach. Podobnie jest w Kanadzie, Polsce i Chinach, gdzie biura korporacji zlokalizowane są w trzech miastach (tab. 2, ryc. 2).

Tab. 2. Lokalizacja oddziałów firmy Google na świecie

\begin{tabular}{|c|c|c|c|}
\hline Państwo & $\begin{array}{c}\text { Liczba } \\
\text { oddziałów } \\
\text { w państwie }\end{array}$ & $\begin{array}{c}\text { Udzial oddzia- } \\
\text { lów w ogóle }\end{array}$ & Siedziby biur \\
\hline $\begin{array}{c}\text { Stany } \\
\text { Zjednoczone }\end{array}$ & 19 & 29,2 & $\begin{array}{c}\text { Mountain View, Ann Arbor, Atlanta, Austin, } \\
\text { Boulder, Cambridge, Chicago, Detroit, Irvine, } \\
\text { Kirkland, Madison, Nowy Jork (2), Pittsburgh, } \\
\text { Reston, San Francisco, Santa Monica, Seattle, } \\
\text { Waszyngton }\end{array}$ \\
\hline Indie & 4 & 6,2 & Bangalor, Gurgaon, Hajdarabad, Bombaj \\
\hline Kanada & 3 & 4,6 & Montreal, Toronto, Waterloo \\
\hline Polska & 3 & 4,6 & Kraków, Wrocław, Warszawa \\
\hline Chiny & 3 & 4,6 & Pekin, Guangzhou, Szanghaj \\
\hline
\end{tabular}




\begin{tabular}{|c|c|c|c|}
\hline Dania & 2 & 3,1 & Arhus, Kopenhaga \\
\hline Niemcy & 2 & 3,1 & Hamburg, Monachium \\
\hline Rosja & 2 & 3,1 & Moskwa, St. Petersburg \\
\hline Szwecja & 2 & 3,1 & Sztokholm, Luleå \\
\hline Izrael & 2 & 3,1 & Hajfa, Tel Awiw \\
\hline Belgia & 1 & 1,5 & Bruksela \\
\hline Finlandia & 1 & 1,5 & Helsinki \\
\hline Francja & 1 & 1,5 & Paryż \\
\hline Węgry & 1 & 1,5 & Budapeszt \\
\hline Irlandia & 1 & 1,5 & Dublin \\
\hline Włochy & 1 & 1,5 & Milan \\
\hline Holandia & 1 & 1,5 & Amsterdam \\
\hline Norwegia & 1 & 1,5 & Oslo \\
\hline Hiszpania & 1 & 1,5 & Madryt \\
\hline Szwajcaria & 1 & 1,5 & Zurych \\
\hline Wielka Brytania & 1 & 1,5 & Londyn \\
\hline Hongkong $^{3}$ & 1 & 1,5 & Hongkong \\
\hline Japonia & 1 & 1,5 & Tokio \\
\hline Korea Południowa & 1 & 1,5 & Seul \\
\hline Singapur & 1 & 1,5 & Singapur \\
\hline Tajwan $^{4}$ & 1 & 1,5 & Tajwan \\
\hline Turcja & 1 & 1,5 & Istambuł \\
\hline $\begin{array}{c}\text { Zjednoczone } \\
\text { Emiraty } \\
\text { Arabskie }\end{array}$ & 1 & 1,5 & Dubaj \\
\hline Argentyna & 1 & 1,5 & Buenos Aires \\
\hline Brazylia & 1 & 1,5 & São Paulo \\
\hline Meksyk & 1 & 1,5 & Lomas de Chapultepec \\
\hline Australia & 1 & 1,5 & Sydney \\
\hline Ogółem & 65 & 100,0 & \\
\hline
\end{tabular}

Źródło: opracowanie własne na podstawie www.google.com.

${ }^{3}$ Region administracyjny Chin, potraktowany oddzielnie ze względu na dużą autonomię we wszystkich sprawach, z wyjątkiem polityki zagranicznej i sił zbrojnych.

${ }^{4}$ Uznawany za 23 prowincję Chin, dla potrzeb pracy potraktowany oddzielnie ze względu na suwerenne, demokratyczne władze prowadzące prawie niezależną politykę zagraniczną. 


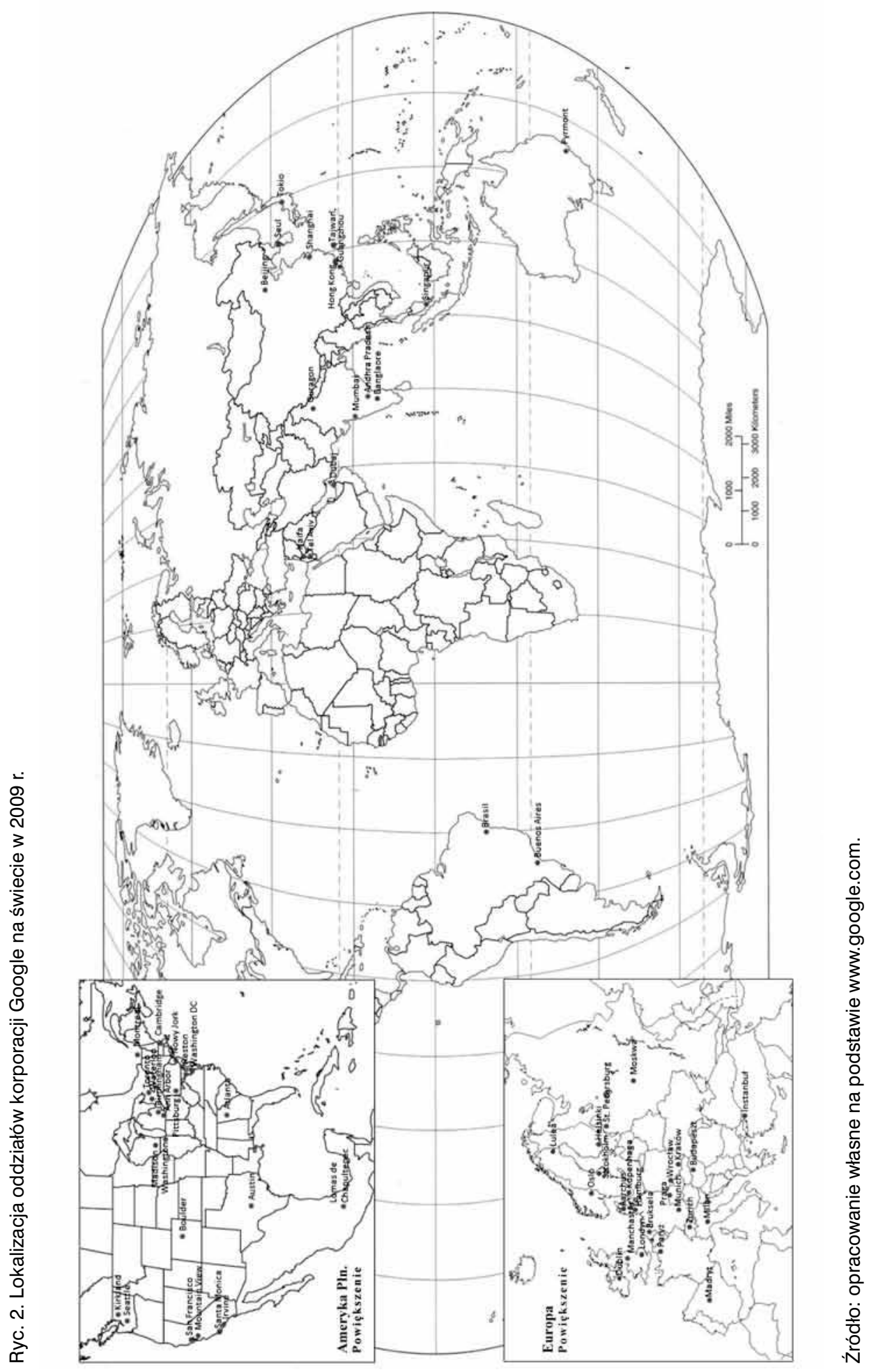


Poszczególne regiony świata odznaczają się zróżnicowanym potencjałem oddziałów korporacji Google, co wyrażono wartościa przychodu oraz wartością aktywów. W materiałach źródłowych dotyczących wartości przychodu dokonano podziału na Stany Zjednoczone, Wielką Brytanię i resztę świata w przedziale czasowym od 2006 do 2009 r. Natomiast w wypadku wartości aktywów wyróżniono tylko Stany Zjednoczone na tle reszty świata w przedziale czasowym od 2007 do 2009 r.

Biorąc pod uwagę zróżnicowanie wartości przychodu osiąganego przez poszczególne kraje, na terenach których występują biura firmy Google, zauważono dominację siedzib zlokalizowanych w Stanach Zjednoczonych. Wartość przychodu siedzib firmy Google w Stanach Zjednoczonych zwiększyła się w latach 2006-2009 z 6,0 do 11,2 mld USD (tab. 3), tj. prawie dwukrotnie, co stanowiło od 56,6\% do 47,3\% ogółu wartości przychodu wygenerowanego przez korporację. Wysoką wartość przychodu osiągnęły także biura usytuowane w Wielkiej Brytanii - wzrosła ona z 1,6 mld USD w 2006 do 3,0 mld USD w 2009 r., tj. prawie dwukrotnie, co stanowiło od 15,1\% do 12,6\% ogólnych przychodów firmy. Pozostałe oddziały znajdujące się w innych częściach świata łącznie charakteryzowały się intensywnym wzrostem wartości przychodu z 3,0 mld USD do 9,5 mld USD, tj. ponad trzykrotnym. W związku z dynamicznym wzrostem wartości przychodu tych oddziałów ich udział zwiększył się w ogóle przychodu firmy Google z 28,3\% w 2006 r. do 40,0\% w 2009 r. Mimo wzrostu wartości przychodu biur Google zlokalizowanych w Stanach Zjednoczonych w latach 2006-2009 udział ich wartości w ogóle osiągniętego przychodu zmniejszył się na rzecz oddziałów znajdujących się w pozostałych częściach świata, co oznacza zwiększenie się intensywności opanowywania rynków światowych.

Tab. 3. Zróżnicowanie wartości przychodu firmy Google na świecie w latach 2006-2009

\begin{tabular}{|c|r|r|r|r|r|r|r|r|r|}
\hline Rok & $\mathbf{2 0 0 6}$ & $\mathbf{2 0 0 7}$ & $\mathbf{2 0 0 8}$ & $\mathbf{2 0 0 9}$ & $\mathbf{2 0 0 6}$ & $\mathbf{2 0 0 7}$ & $\mathbf{2 0 0 8}$ & $\mathbf{2 0 0 9}$ \\
\hline & \multicolumn{4}{|c|}{ Wartość przychodu (mld USD) } & \multicolumn{4}{|c|}{ Udział w ogóle przychodu } \\
\hline USA & 6,0 & 8,7 & 10,6 & 11,2 & 56,6 & 52,4 & 48,8 & 47,3 \\
\hline Wielka Brytania & 1,6 & 2,5 & 3,0 & 3,0 & 15,1 & 15,3 & 13,9 & 12,6 \\
\hline Reszta świata & 3,0 & 5,4 & 8,1 & 9,5 & 28,3 & 32,3 & 37,3 & 40,0 \\
\hline Ogółem & 10,6 & 16,6 & 21,8 & 23,7 & 100,0 & 100,0 & 100,0 & 100,0 \\
\hline
\end{tabular}

Źródło: opracowanie własne na podstawie www.google.com.

Podobnie biura zlokalizowane w Stanach Zjednoczonych odgrywały dominującą rolę w firmie Google pod względem wartości aktywów. Wartość majątku (aktywów) zgromadzonego przez Google w Stanach Zjednoczonych w latach 2007-2009 zwiększyła się z 7,3 mld USD do 9,4 mld USD (tab. 4), tj. o 22\%, przy czym jego udział w ogóle aktywów firmy spadł z 91,2\% do $83,3 \%$. Wartość majątku pozostałych oddziałów wzrosła z 0,7 mld USD do 1,9 mld USD, tj. o 66,7\%, w związku z czym jego udział wzrósł z 8,8\% do 16,7\% ogółu aktywów należących do korporacji. Zmniejszanie się udziału wartości aktywów oddziałów znajdujących się w Stanach Zjednoczonych, a zwiększanie się udziału wartości aktywów biur w pozostałych częściach świata potwierdza tendencję korporacji Google do intensywnego opanowywania kolejnych rynków światowych. 
Tab. 4. Zróżnicowanie wartości aktywów firmy Google na świecie w latach 2007-2009

\begin{tabular}{|c|c|c|c|c|c|c|c|}
\hline Rok & $\mathbf{2 0 0 7}$ & $\mathbf{2 0 0 8}$ & $\mathbf{2 0 0 9}$ & $\mathbf{2 0 0 7}$ & $\mathbf{2 0 0 8}$ & $\mathbf{2 0 0 9}$ \\
\hline & \multicolumn{2}{|c|}{ Wartość aktywów (mld USD) } & \multicolumn{2}{|c|}{ Udział w ogóle aktywów (\%) } \\
\hline USA & 7,3 & 9,8 & 9,4 & 91,2 & 84,4 & 83,3 \\
\hline Reszta świata & 0,7 & 1,8 & 1,9 & 8,8 & 15,6 & 16,7 \\
\hline Ogółem & 8,0 & 11,6 & 11,3 & 100,0 & 100,0 & 100,0 \\
\hline
\end{tabular}

Źródło: opracowanie własne na podstawie www.google.com.

Korporacja zlokalizowała swoje oddziały także na terenie Polski: w Warszawie, Krakowie oraz we Wrocławiu.

Oddział w Warszawie został utworzony w 2005 r. i składa się z zespołów zajmujących się marketingiem i sprzedażą, działalnością operacyjną oraz public relations. Kreatywna kadra specjalistów ma na celu zapewnienie obsługi na najwyższym poziomie partnerom firmy, użytkownikom i reklamodawcom w Europie Środkowej i Wschodniej.

W 2007 r. otwarto centrum badawczo-rozwojowe w Krakowie, które w przeciągu roku stało się trzecim co do wielkości centrum badawczo-rozwojowym regionu. Krakowskie biuro Google nie specjalizuje się w określonym produkcie, natomiast inżynierowie pracują w nim nad rozwiązaniami globalnymi. Dodatkowo, Kraków jest miejscem pracy nad globalnymi projektami dla zespołów z Czech i Słowacji, które dostarczają produkty Google na tamtejszy rynek. W połowie 2008 r. krakowskie centrum zatrudniało 60 inżynierów z 17 różnych krajów, w tym przyjęto osoby bez stażu pracy, jak również osoby z ponad trzydziestoletnim doświadczeniem w pracy nad oprogramowaniem.

Trzecie biuro na terenie Polski otwarto we Wrocławiu. Centrum innowacji we Wrocławiu zajmuje się obsługą użytkowników w różnych językach, z różnych krajów, a dzięki współpracy z centrum badawczo-rozwojowym w Krakowie angażuje się w testowanie nowych innowacyjnych rozwiązań Google. Spełnia ono rolę „,centrum doskonałości” zarówno dla użytkowników, reklamodawców, jak i wydawców.

\section{Technologia i działalność firmy}

Larry Page uważa, że: ,idealna wyszukiwarka to taka, która zrozumiałaby, dokładnie czego potrzebujesz i zwróciłaby dokładnie to, czego chcesz", dlatego też stworzenie takiej wyszukiwarki było celem firmy od początku jej działalności. Wynik, który uzyskano, można scharakteryzować w kilku słowach: prędkość, trafność, obiektywność i łatwość użytkowania.

Poprzez innowacyjność Page i Brin stali się prekursorami w wyszukiwaniu informacji i opracowali własną infrastrukturę usługową dzięki przełomowej technologii PageRank ${ }^{\mathrm{TM}}$. Dokonuje ona obiektywnej oceny ważności stron internetowych na podstawie liczby oraz autorów oddanych na nią głosów. Ważne strony uzyskują wyższe notowanie PageRank i są wyświetlane na początku listy wyników wyszukiwania. Obecnie zaawansowany proces wyszukiwania umożliwia uzyskanie odpowiedzi na konkretne pytanie użytkownika, nie wymagając przekierowania bieżącego widoku do witryny zawierającej zdefiniowane zagadnienie.

W celu szybkiego znajdywania odpowiedzi na pytania zamiast kilku wielkich serwerów, firma Google zastosowała połączone komputery. Zapewniło to krótszy czas reakcji, większą skalowalność i mniejsze koszty. Sposób, w jaki dochodzi do uzyskania informacji, przedstawia rycina 2. 
Ryc. 2. Cykl życia zapytania Google

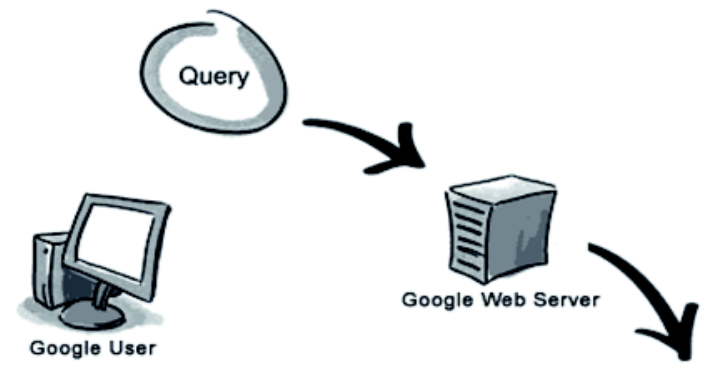

3. Wyniki wyszukiwania są zwracane użytkownikowi w ciągu ułamka sekundy.

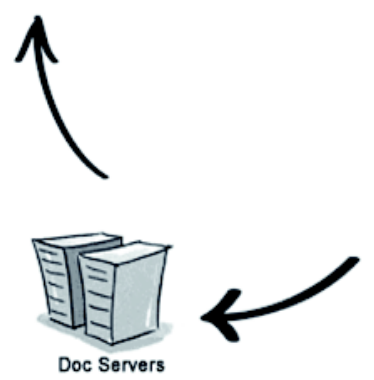

Źródło: www.google.pl.
1. Serwer internetowy wysyła zapytanie do serwerów indeksu. Zawartość obsługiwana przez serwery indeksu jest podobna do indeksu umieszczonego na końcu książki - zawiera ona informacje o tym, na których stronach znajdują się słowa pasujące do zapytania.

2. Zapytanie jest wysyłane do serwerów dokumentów, które pobierają przechowywane dokumenty. Generowane są fragmenty opisujące każdy wynik wyszukiwania.

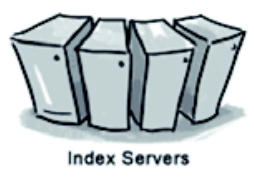

Index Servers

Firma Google postawiła na prostotę serwisu. Projekt witryny jest przejrzysty i wygodny w użytkowaniu, ponieważ nie zawiera zbędnych elementów dekoncentrujących internautów, a wyniki wyszukiwania są wyraźnie oddzielone od reklam, które zaznaczono jako „linki sponsorowane" (ryc. 3). Minimalistyczny układ witryny obsługującej wyszukiwarkę internetową Google został opatentowany.

Ryc. 3. Projekt witryny Google

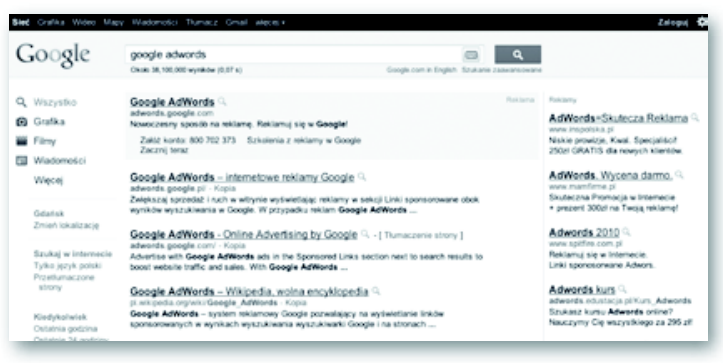

Źródło: www.google.pl.

W 2010 r. wyszukiwarka zyskała nowy układ graficzny, który ma lepiej prezentować użytkownikowi możliwości oraz ujednolicić pod względem graficznym poszczególnych funkcje wyszukiwania (ryc. 4). 
Ryc. 4. Współczesna wersja witryny Google

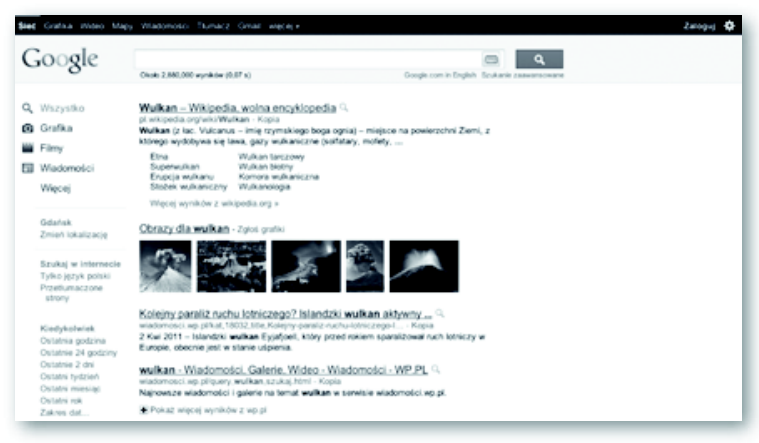

Źródło: http://nt.interia.pl/internet/wiadomosci/news/duze-zmiany-w-google,1474626.

Dysponując technologią wyszukiwania najwyższej klasy oraz obserwując ogromny ruch w witrynie Google.com, firma jako dwie początkowe możliwości pozyskiwania przychodów uznała usługi wyszukiwania i reklamy, które z czasem przekształciły się w dopełniające się sieci. Współcześnie najbardziej dochodowymi usługami Google jest wyszukiwarka internetowa oraz serwisy reklamowe AdWords i AdSense, jednak doświadczenie zespołu, zachodzące zmiany technologiczne, rosnące zainteresowanie użytkowników, a co za tym idzie - coraz większe zyski, umożliwiły poszerzenie oferty korporacji. Szeroki wachlarz usług proponowanych przez firmę Google przedstawia się następująco:

- wyszukiwanie internetowe (Internet Search),

- reklamy internetowe (Online Advertising),

- aplikacje internetowe (Web Applications),

- usługi biznesowe (Enterprise Services),

- rynek urządzeń mobilnych (the Market of Mobile Devices).

Usługi wyszukiwania internetowego umożliwiają internautom szybki dostęp do licznych stron zawierających informacje na interesujący ich temat. Są podzielone na kategorie takie jak: finanse (Finance), obrazki (Images), mapy (Maps), informacje (News), katalogi stron internetowych stworzone przez użytkowników (Directory). Warto wspomnieć także o przeglądarce internetowej Google Chrome oraz Froogle, czyli wyszukiwarce dla e-handlu.

Google posiada dwa systemy reklamowe: AdSense i AdWords. AdSense to usługa, która umożliwia wyświetlanie reklam adekwatnych do treści stron, a wydawca ma swój udział w przychodach generowanych przez czytelników klikających w reklamy. AdWords umożliwia reklamodawcom promocję produktów i usług w sieci przy użyciu profilowanych reklam „linków sponsorowanych” - przyciągających użytkowników z grup docelowych. Wybierają oni kluczowe słowa i płacą, gdy zainteresowani internauci klikną w ich reklamy. Firma oferuje także serwis „Analytics”, służący pomocą reklamodawcom, wydawcom i właścicielom stron przy identyfikacji haseł, reklam, skierowań i kampanii.

Aplikacje internetowe obejmują następujące usługi:

- Gmail - poczta elektroniczna i bezpłatny serwis webmail, pojemność skrzynki pocztowej w serwisie przekracza 7 gigabajtów i jest ciągle zwiększana,

- Google Groups - grupy dyskusyjne, umożliwiające zarządzanie listami mailingowymi oraz ich archiwizowanie, 
- Calendar - stosunkowo zaawansowana aplikacja do zarządzania własnym terminarzem,

- Google Talk - komunikator internetowy wyposażony w funkcjonalność VoIP (Voice over Internet Protocol),

- Google Wave - umożliwiające komunikację i współtworzenie dokumentów multimedialnych w czasie rzeczywistym,

- Analytics - system analizy ruchu sieciowego dostępny dla każdego użytkownika Google,

- YouTube - serwis internetowy, w którym użytkownicy mogą umieszczać i oglądać filmy wideo,

- Blogger - darmowy serwis blogowy,

- Picasa - menadżer i przeglądarka plików graficznych, umożliwia organizowanie kolekcji zdjęć cyfrowych i ich prostą edycję,

- Picasa Web Albums - serwis internetowy umożliwiający publikację w Internecie albumów zdjęć cyfrowych bezpośrednio z programu Picasa lub z poziomu przeglądarki.

Usługi biznesowe gwarantują korporacjom większą wydajność pracowników poprzez połączenie innowacyjności i łatwości obsługi produktów firmy Google oraz bezpieczeństwo organizacji. Dzielą się one na:

- Google Apps - redukujące koszty takich usług, jak: Gmail dla biznesu, Google Calendar, Google Groups, Google Docs, Google Sites i Google Video,

- Google Earth and Maps - ułatwiające pracownikom zrozumienie i podejmowania decyzji na podstawie informacji opartych na lokalizacji. Uwzględnienie danych firmy w Google Maps i Google Earth powoduje, że mogą być one szybko i łatwo wymienianie ze współpracownikami i klientami,

- Google Search - umożliwiający szybkie wyszukiwanie stron biznesowych na interesujący użytkownika temat.

Rynek urządzeń mobilnych obejmuje aplikacje działające w telefonach komórkowych, np. wyszukiwarkę internetową, YouTube, Gmail, SMS, Calendar, News, Maps oraz Google Latitude. Powstała także platforma dla telefonów komórkowych - Android - oparta na systemie Linux.

Firma Google dywersyfikuje swoje produkty i wchodzi na nowe rynki w celu kompleksowego zaspokajania potrzeb odbiorców. W czerwcu 2009 r. zapowiedziała poszerzenie swojej oferty o system operacyjny Chrome OS, posiadający otwarte źródła, którego głównym zadaniem ma być uruchamianie aplikacji internetowych. Oficjalna premiera systemu jest przewidziana na drugą połowę $2010 \mathrm{r}$.

Na przełom czerwca i lipca 2010 r. firma planowała wprowadzenie serwisu Google Editions służącego do sprzedaży elektronicznych książek, które będą pochodzić z różnych stron internetowych i będą możliwe do odczytania na różnych urządzeniach. Podstawą działania serwisu ma być wyszukiwarka Google Books.

Za sprawą systematycznych przejęć konkurencyjnych działalności Google proponuje coraz nowsze produkty i usługi. Jeden z ostatnich zakupów to BumpTop, który może okazać się konkurencyjnym produktem dla Apple i jego iPhone'a oraz iPada.

\section{Struktura wewnętrzna Google}

W wyniku procesu rozszerzania oraz doskonalenia produktów i usług, a także opanowywania nowych rynków zbytu, w firmie Google ukształtowała się odpowiednia do uwarunkowań struktura organizacyjna, której zadaniem jest podnoszenie konkurencyjności. W strukturze tej wyróżniono następujące segmenty powstałe w celu kompleksowego zaspokajania potrzeb klientów: 
- Engineering Operations - dział zajmujący się rozwojem i projektowaniem nowych aplikacji,

- Advertising Sales - oddział zajmujący się dostosowywaniem systemu reklamowego do konkretnych potrzeb klienta oraz Customer Supprot - dział, którego zadaniem jest wspieranie techniczne użytkowników i rozwiązywanie problemów związanych z usługami i aplikacjami Google,

- Product Management - segment dbający o rozwój i zarządzanie usługami w celu zapewnienia lepszego dostępu do zasobów informacji,

- Marketing and Communications - dział zajmujący się marketingiem oraz promowaniem firmy na rynku światowym,

- User Experience - segment badający zachowania i wymagania internautów oraz przyjmujący sugestie użytkowników w celu poprawienia jakości oferowanych produktów i usług,

- Legal and Public Politycy - sekcja regulująca kwestie prawne korporacji,

- Bussines Operations - dział specjalizujący się w efektywnym inicjowaniu i wdrażaniu programów partnerskich z innymi korporacjami,

- Administrative - dział zajmujący się koordynacją pracy poszczególnych zespołów Google w celu skutecznego rozwoju usług, aplikacji oraz całej firmy,

- Enterprise - segment wdrażający swoje produkty i usługi w firmach, placówkach oświatowych oraz organizacjach rządowych,

- Finance - dział zarządzający operacjami finansowymi i prowadzący analizę finansową przedsiębiorstwa,

- Human Resources - segment zajmujący się pozyskiwaniem przyszłych pracowników oraz stwarzaniem odpowiednich warunkach do pracy dotychczasowym kadrom.

\section{Strategia Google}

Kierunek rozwoju korporacji określa strategia rozwoju, w której ustala się misję i cele rozwojowe firmy na tle istniejących uwarunkowań w gospodarce światowej. „Strategia koncentruje się na zrozumieniu otoczenia i formułowaniu polityki przedsiębiorstwa, tak by mogło ono osiągnąć korzystną pozycję w stosunku do konkurentów" (Tobolska 2006, s. 125), wykorzystywać pojawiające się szanse i redukować zagrożenia pojawiające się na rynku.

W przeciągu 12 lat w korporacji Google dokonał się hiperrozwój. Na podstawie cech korporacji, jej działalności i podejmowanych przez nią decyzji, a także ogólnie przyjętych kierunków rozwoju, dokonano próby określenia jej strategii.

Misją firmy jest „uporządkowanie światowych zasobów informacji, aby stały się one powszechnie dostępne i użyteczne". Za główne wyznaczniki strategii firmy Google w okresie 12-lecia jej działalności uznano:

- partnerstwo i zaufanie między firmą a jej klientami i partnerami w interesach,

- maksymalizację zysków niezbędnych do finansowania rozwoju i innych celów strategicznych,

- ciągłe doskonalenie proponowanych produktów i usług, prowadzące do tworzenia oferty najwyższej jakości w swojej dziedzinie, gwarantujące uznanie oraz lojalność klientów i nabywców na całym świecie,

- dywersyfikację produktów i wchodzenie na nowe, pokrewne rynki w celu kompleksowego zaspokajania potrzeb odbiorców,

- lokalizację nowych oddziałów w różnych krajach w celu dopasowania oferty ściśle do wymagań każdej grupy użytkowników,

- innowacyjność w każdej sferze działalności,

- badania i rozwój nowych technologii, 
- strategię zarządzania ludźmi, gwarantującą pełną swobodę tworzenia (zapewniającą pracownikom $20 \%$ czasu pracy na rozwijanie autorskich projektów) oraz przyjazne środowisko pracy, umożliwiające im relaks i rozwijanie zainteresowań, a także docenianie indywidualnych talentów i osiągnięć pracowników.

W strategii przyjętej przez korporację Google występują elementy strategii firm globalnych eksponujących kapitał ludzki, innowacje oraz jakość.

Na kapitał ludzki składają się kompetencje, wiedza, umiejętności, doświadczenie i talent zarówno menadżerów, jak i pracowników. To kadra decyduje o sprawności i efektywności, a co za tym idzie - o sukcesie firmy, pod warunkiem jednak, że jest zintegrowana ze strategią organizacyjną i strategiami na szczeblu funkcjonalnym. Google swoją przeszłość, teraźniejszość i przyszłość widzi w rozwoju potencjału intelektualnego, stawia na młodych i pomysłowych ludzi, którzy mają w pracy możliwość realizacji własnych idei, ponieważ właśnie z idei studentów zrodziła się ta firma.

W korporacji dostrzeżono cechy firm globalnych eksponujących innowacje, które są nastawione na ciągłe poszukiwanie nowych, lepszych rozwiązań w dziedzinie technologii, organizacji, inwestycji i pracy. Google w procesach innowacyjnych stosuje postawę ukrytych mistrzów (hidden champions). Początkowo firma była uznawana za niegroźną, działającą w cieniu innych globalnych gigantów. Traktuje ona technologie i rynek jako siły napędowe, dlatego w krótkim okresie zagarnęła ponad 80\% rynku światowego w dziedzinie wyszukiwania i zdobyła pozycję monopolistyczną.

Strategia zarządzania przez jakość przejawia się w korporacji Google w krytycznym spojrzeniu na oferowane produkty i usługi, prowadzącym do ich ciągłego ulepszania i gwarantowania pełnej satysfakcji odbiorcom. Dla firmy tak samo ważny jest klient wewnętrzny, czyli pracownik, jak i klient zewnętrzny, czyli końcowy użytkownik usługi. Podejście do jakości uznaje się jako kompleksowe, a jakość nadrzędną stanowi myślenie procesowe. Procesy są analizowane i optymalizowane $\mathrm{w}$ dążeniu do perfekcji.

Google w stosunku do konkurencji unika frontalnego ataku. Przykładem napoleońskiej taktyki biznesowej jest nawiązanie stosunków z gigantem wyszukiwania - Yahoo, wprowadzenie działalności portalowej oraz wprowadzenie usługi Gmail (Minakowski 2008).

Google, współpracując z Yahoo, oprócz dostarczania wyników wyszukiwania owej wyszukiwarki działało pod własnym szyldem. Firma zastosowała strategię „okrążania” i otworzyła się na cały świat, tłumacząc swój interfejs na wszystkie możliwe języki (także na polski). Przewagą Google był interfejs użytkownika w kodowaniu Unicode, którego jeden parametr tłumaczył wszystkie teksty na dowolny, obsługiwany język. Korporacja budowała swoją pozycję zagraniczną, podbijając kolejne rynki w dziedzinie wyszukiwarek.

Początkowo twórcy zrezygnowali z działalności portalowej, jednak wraz z rozwojem firmy wszystkie elementy portalowe znalazły się na iGoogle, a korporacja stała się niespodziewanie rywalem dla innych portali.

Firma osiągnęła ogromy sukces w przypadku poczty elektronicznej dzięki temu, że zwróciła uwagę na problem dodawania do wiadomości załączników o dużych rozmiarach. W ten oto sposób wypełniła niszę, tworząc usługę Gmail i udostępniając gigabajtowe skrzynki, których pojemność jest wciąż zwiększana.

Obecnie rynek wyszukiwarek jest na pograniczu oligopolu i monopolu. Największe udziały w nim posiadają: Google (81,1\%), Yahoo (10,5\%), MSN/Live (4,6\%), AOL - Global (2,0\%), a pozostałe wyszukiwarki to zaledwie $1,8 \%$ udziału w rynku (ryc. 5). Sytuacja ta jest odzwierciedleniem zmian, które nastąpiły w ostatnich latach w komunikacji elektronicznej. 
Ryc. 5. Udział poszczególnych wyszukiwarek w rynku wyszukiwarek ogółem w 2009 r.

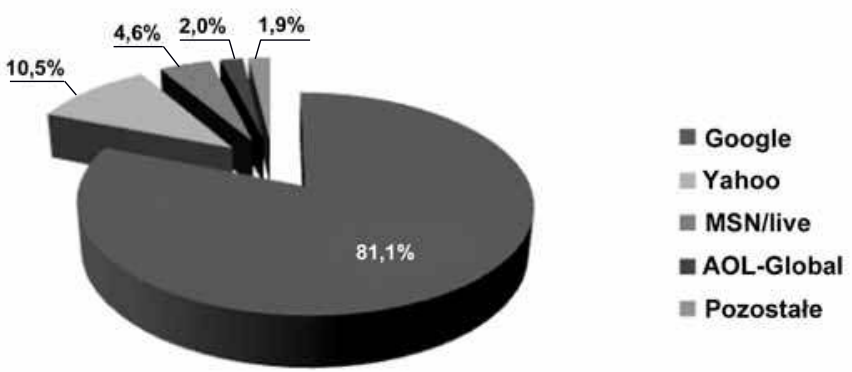

Źródło: opracowanie własne na podstawie http://www.strategie.biz.pl/2009/02/23/potrzeba-matka-wynalazku-i-sukcesu/.

Firma Google pobija rekordy w liczbie przejętych spółek. Od momentu narodzin internetowego giganta maksymalny wynik padł w roku 2007, kiedy przejął 16 spółek, a tylko do czerwca w 2010 r. przejęła 11 spółek i wciąż czeka na zgodę regulatorów transakcji roku poprzedniego (Grynkiewicz 2010). W okresie od 2001 r. do czerwca 2010 r. dokonała 70 przejęć, podczas gdy Microsoft w ciągu 23-letniej historii przejął 128 spółek. Najdroższym nabytkiem Google jest Double Click - firma zajmująca się reklamą internetową - warta 3,1 mld USD. Znaczną większość, bo aż 51 firm przejętych przez korporację, stanowią firmy amerykańskie.

Ogromna przewaga korporacji nad konkurencją wynika z zasady, która stawia skupienie uwagi internautów na użytecznych funkcjach serwisu i rezultatach wyszukiwania. Promocja serwisu jest bardzo subtelna i przemyślana, największą siłą i reklamą jest sam oferowany produkt, a także strategia przyjęta przez korporację w dążeniu do doskonałości. Bardzo ważne znaczenie w podnoszeniu nowoczesności oferowanych produktów ma nauka (Zioło 2009).

Wskazane przykłady postępowania firmy Google świadczą o tym, że potrafi celnie wskazywać potrzeby odbiorców, a także skutecznie je realizować. Głównym celem dalszego rozwoju korporacji jest podnoszenie standardu produktów i usług, doskonalenie metod w zakresie wyszukiwania, systematyczne pogłębianie i rozszerzanie rynku w poszczególnych krajów, jak i światowego, a także ograniczanie kosztów związanych z intensyfikacją rozwoju firmy, a tym samym zmniejszenie kosztów użytkowników, co jest znaczącym czynnikiem podnoszenia konkurencyjności.

\section{Filozofia i kultura Google}

Fenomenem, który udało się osiągnąć założycielom Google, jest fakt, że pomimo hiperrozwoju od momentu narodzin firmy w 1998 r. udało się jej zachować pierwotne wartości i atmosferę małego przedsiębiorstwa.

W celu realizacji misji korporacji i skutecznego tworzenia nowej kultury pracy, wprowadzono pewne zasady postępowania obowiązujące w Google aż do dziś. Credo firmy stanowią słowa wypowiedziane przez jednego z inżynierów, Paula Buchheita: „Nie bądź zły” (Don ’t be evil), wskazujące sposób, w jaki powinna ona prowadzić swoją działalność na arenie międzynarodowej.

W firmie Google priorytetem jest innowacyjność oraz efektywność. Największą wartość stanowi dla niej kapitał ludzki, dlatego poszukuje utalentowanych i kreatywnych pracowników, którzy potrafią sprostać stawianym przed nimi wymaganiom oraz realizować cele korporacji. Prowadzona jest otwarta polityka rekrutacyjna, liczy się wiedza, umiejętność rozwiązywania 
problemów, przedkładane są uzdolnienia nad doświadczenie. Atutem korporacji jest jej niezwykła i ciekawa kultura organizacyjna.

Motto zarządu brzmi: „Inwestycja w pracownika jest inwestycją w firmę”. Efektywność oraz zaangażowanie we wprowadzanie innowacji zależy m.in. od tego, czy Googlersi ${ }^{3}$ czują się swobodnie w miejscu pracy, dlatego zarząd dokłada wszelkich starań, aby zapewnić pracownikom odpowiednie środowisko do tworzenia nowatorskich projektów i technologii, a także umożliwić im rozwijanie ich pasji poprzez tworzenie grup o wszelakich zainteresowaniach. Filozofią Google jest możliwość stworzenia „młodości” warunków do samorealizacji, a tym samym tworzenia podstaw do rozwoju firmy.

Pracownicy działają w małych, trzy- lub czteroosobowych zespołach, przez co mogą szybciej realizować swoje koncepcje, nie czują korporacyjnej presji i poprawiają kontakty interpersonalne. Specyfiką firmy jest przeznaczenie $20 \%$ czasu pracownika na rozwijanie autorskich, nowatorskich projektów, które mają szansę późniejszej realizacji.

Biura Google są zaprojektowane tak, aby wzbudzać wśród pracowników skojarzenia z rozrywką. Posiadają wiele charakterystycznych elementów gwarantujących pracownikom komfort i możliwość relaksu, który wpływa na ich wysoką wydajność i jakość wykonywanych przez nich zadań. Fotele masujące i duże dmuchane piłki, piłkarzyki, stoły bilardowe, boiska do siatkówki, gry wideo, pianina oraz sale gimnastyczne, w których odbywają się zajęcia jogi i tańca, to tylko niektóre propozycje. Googlersi mają do dyspozycji rowery i skutery, które pozwalają im przemieszczać się z jednego spotkania na drugie. Pracownicy mają zagwarantowane zdrowe i pełnowartościowe obiady i kolacje w rozmaitych kantynach i pokoje socjalne wypełnione różnymi przekąskami i napojami, które pomagają im zachować siły i skupienie. Biura Google są bogate w akcenty typowe dla miejsca ich lokalizacji, np. gondole kolejki linowej w Zurychu, odzwierciedlające jego atmosferę i charakter.

W 2009 r. korporacja Google znalazła się na czwartej pozycji (za NetApp, Edward Jones i Boston Consulting Group) w rankingu ,100 najlepszych pracodawców” (,100 Best Companies to Work For”) prestiżowego magazynu „Fortune”, w którym od trzech lat utrzymywała się w pierwszej piątce.

W świetle przedstawionego procesu kształtowania się korporacji ponadnarodowej Google i postępującej globalizacji można stwierdzić, że rozwój korporacji zostanie zachowany. Ciągłe innowacje technologiczne, troska o najwyższą jakość produktów i usług mają na celu sprostać coraz to nowszym oczekiwaniom klientów, a w połączeniu z zarządzaniem zorientowanym na ludzi decydują o sukcesie korporacji.

Dzięki wierności swej filozofii oraz strategii sukcesu firma zdobyła czołową pozycję wśród korporacji branży informatycznej, a także w krótkim czasie stała się częścią życia, niewzbudzającym zaskoczenia elementem rzeczywistości, bez którego niektórzy nie wyobrażają sobie życia. To google stało się synonimem słowa szukać, a Google często utożsamiane jest z Internetem (Maleńczak 2009). O wielkości i roli giganta internetowego, której nie da się przeliczyć na miliardy dolarów świadczą słowa wypowiedziane przez Brewstera Kahle ${ }^{4}$, Biblioteka aleksandryjska była pierwszą próbą zebrania w jednym miejscu całej wiedzy ludzkości. Ostatnia taka próba to Google".

\footnotetext{
${ }^{3}$ Określenie pracowników firmy Google.

${ }^{4}$ Przedsiębiorca, inżynier komputerowy i założyciel the Internet Archive.
} 


\section{Literatura}

1. Battelle J., 2006, The Search. How Google and its Rivals Rewrote the Rules of Business and Transformed Our Culture, Wydawnictwo Naukowe PWN, Warszawa.

2. Boguś M., 2010, Kształtowanie się korporacji ponadnarodowej Google, praca magisterska napisana w Zakładzie Przedsiębiorczości i Gospodarki Przestrzennej, Instytut Geografii Uniwersytetu Pedagogicznego im. Komisji Edukacji Narodowej w Krakowie pod kierunkiem prof. Z. Zioło.

3. Grynkiewicz T., 2010, Giganci IT maja w gotówce 188 mld dol., „Gazeta Wyborcza. Gospodarka”, nr 27.

4. http://openzone.pl/news,krotka-historia-google,3000.

5. Kilar W., 2009, Zróżnicowanie potencjału ekonomicznego światowych korporacji [w:] Funkcje przemysłu w kształtowaniu społeczeństwa informacyjnego, Z. Zioło, T. Rachwał (red.), „Prace Komisji Geografii Przemysłu PTG”, nr 13, Komisja Geografii Przemysłu PTG i Instytut Geografii Uniwersytetu Pedagogicznego w Krakowie, Warszawa-Kraków, s. 110-121.

6. Maleńczak P., Potrzeba matka wynalazku (i sukcesu)!, www.strategie.biz.p1/2009/02/23/potrzeba-matka-wynalazku-i-sukcesu/

7. Olszak C., Ziemba E., 2007, Strategie i modele gospodarki elektronicznej, Wydawnictwo Naukowe PWN, Warszawa.

8. Piórko K., 2008, „Władza” korporacji transnarodowych $w$ stosunkach międzynarodowych, Wydawnictwo Naukowe GRADO, Toruń.

9. Tobolska A., 2006, Strategie globalne a nowe formy organizacji przedsiębiorstw transnarodowych [w:] Rola przedsiębiorczości w podnoszeniu konkurencyjności społeczeństwa i gospodarki, Z. Zioło, T. Rachwał (red.), „Przedsiębiorczość - Edukacja”, nr 2, Nowa Era, Zakład Przedsiębiorczości i Gospodarki Przestrzennej Instytutu Geografii Akademii Pedagogicznej w Krakowie, Warszawa-Kraków.

10. Vise D., Malseed M., 2007, The Google Story, Wydawnictwo Dolnośląskie, Wrocław.

11. Wieloński A., 2003, Przemyst nowej gospodarki [w:] Przemyst w procesie globalizacji, Z. Zioło, Z. Makieła (red.), „Prace Komisji Geografii Przemysłu PTG”, nr 6, Komisja Geografii Przemysłu PTG w Warszawie i Zakład Przedsiębiorczości i Gospodarki Przestrzennej Instytutu Geografii Akademii Pedagogicznej w Krakowie, Warszawa-Kraków, s. 21-26.

12. www.google.com

13. Zioło Z., 2001, Struktura branżowa i koncentracja przestrzenna wiodacych światowych firm przemystowych [w:] Problemy przemian struktur przemystowych a $w$ procesie wdrażania regut gospodarki rynkowej, Z. Zioło (red.), „Prace Komisji Geografii Przemysłu PTG”, nr 3, Komisja Geografii Przemysłu Polskiego Towarzystwa Geograficznego w Warszawie, Wydział Ekonomiczny UMCS w Lublinie - Filia w Rzeszowie, Warszawa-Kraków-Rzeszów, s. 29-41.

14. Zioło Z., 2009, Procesy kształtowania się światowych korporacji i ich wplyw na otoczenie [w:] Wptyw procesów globalizacji i integracji europejskiej na transformacje struktur przemysłowych, Z. Zioło, T. Rachwał (red.), „Prace Komisji Geografii Przemysłu PTG”, nr 12, Komisja Geografii Przemysłu PTG i Zakład Przedsiębiorczości i Gospodarki Przestrzennej Instytutu Geografii Akademii Pedagogicznej w Krakowie, Warszawa-Kraków.

15. Zorska A., 2002, Korporacje międzynarodowe w Polsce. Wyzwania $w$ dobie globalizacji i regionalizacji, A. Zorska (red.), Difin, Warszawa. 


\section{The Formation of the Multinational Corporation Google}

The formation process of any multinational corporation is driven by mechanisms of competition within global markets. In this modern era of knowledge there is an intensive development of high technology industries, mainly software, which play important roles in the various stages of processing and creation of innovative products and services.

The history of Google goes back to 1995 when its founders - Sergey Brin and Larry Page met at Stanford University in California. On 7th September 1998, Google Inc. was officially incorporated. In 2001 Eric Smidt became Chief Executive Officer. In their twelve years of existence, the company maintained major development and was at the forefront of the development of software industry standards. The most profitable and constantly developing services of the corporation are the search engine, which represents more than $80 \%$ of the total search market and the advertising services such as AdWords and AdSense. However, the company diversifies its products and systematically enters into new markets in order to comprehensively meet the needs of its customers. Its diversification includes web applications, enterprise services and the market of mobile devices.

The various departments of the corporation are located in 70 cities across 39 countries, usually in the capitals of these countries or, if not, in other large cities, which are associated with major public markets. The headquarters of Google is located in Mountain View, California. Most of the departments - twenty three, are located throughout North America and Europe. There are also 16 departments based in Asia. Individual countries have a varying degree of presence of Google offices, the largest being the United States with nineteen, whilst three are located in Poland, in Warsaw, Cracow and Wroclaw.

Google has formed an organizational structure whose main task is to improve its competitiveness. Business development strategy is based on innovation, human potential and high quality standards and its mission is to ,organize the world's information and make it universally accessible and useful". With an effective strategy, Google breaks records in the number of acquired companies.

The Corporation has an unusual and interesting organizational culture, which, due to concern for the well-being of employees, ensures high performance. Google's philosophy is that of developing young, talented individuals capable of self-realization, thus creating a basis for development. In 2009 Google found itself in fourth position in the ranking of "100 Best Companies to Work For" in "Fortune Magazine".

By being faithful to its philosophy and strategy for success, Google has become part of a reality, without which some cannot imagine life. As the company is constantly expanding the range of its services and introducing innovative solutions, it is reasonable to assume that the process of the corporation's development will be maintained. 